\title{
CLINICAL TRIAL OF CALCIUM ORTHO-IODOXYBENZOATE
}

\author{
BY \\ G. D. KERSLEY and N. R. W. SIMPSON \\ From the Royal National Hospital for Rheumatic Diseases, Bath
}

Calcium ortho-iodoxybenzoate and its precursors ortho-iodobenzoic acid and ortho-iodoso-benzoic acid were first described by Meyer and his co-workers in 1892. It contains two double-bonded oxygen atoms linked to the iodine. The use of this product in the treatment of arthritis has been reported on favourably by Young and Youmans (1926); Cottrell (1927); Millard Smith (1927, 1928); Young (1928); Harbinson (1929); and Cohen (1937). Pemberton (1939), however, reported its effect as being merely that of a glorified salicylate. The product has been available commercially as Arthrytin, Artox, Oxo-ate B, Calcoid, and Calsiod.

Conditions of Test.-During the last year a small series of 22 cases of osteo-arthritis, three cases of ankylosing spondylitis, and two cases of rheumatoid arthritis have been the subject of a test of the drug at this hospital. It was made up in tablet form and administered orally. The tablets were supplied in two forms, marked A and B; one contained calcium ortho-iodoxybenzoate (Arthrytin), the other was a "dummy" tablet containing $2 \frac{1}{2}$ gr. aspirin in an inert base. At no time until the conclusion of the test did anyone in the hospital know which tablets contained the drug under trial. The tablets were administered for at least 4 to 6 weeks.

All patients were periodically assessed with regard to pain and limitation of movement; the latter was measured accurately by means of a goniometer. All patients were given routine physiotherapy and hydrotherapy during their stay in hospital, but no other treatment with the exception of the one under trial.

Results.-As regards limitation of movement, all patients showed some slight degree of improvement, but not more so than occurs with physiotherapy and hydrotherapy alone. It was therefore considered that this factor should not be taken into account in estimating the results. The diminishment of pain was of course purely subjective.

Cases given Tablets A.-Nine cases of osteo-arthritis, two cases of rheumatoid arthritis, and three cases of ankylosing spondylitis were treated. All patients said that their pain was diminished to a lesser or greater degree, six of these patients told us that their pain was completely removed by such treatment. Most patients also said that they slept better. We found that the improvement started within 12 hours of beginning medication and stopped within 24 hours of ceasing to take the tablets. We had requests from both patients and their medical practitioners for the name of these tablets after they had returned home. 
Cases given Tablets B.-Thirteen cases of osteo-arthritis were given these tablets. Some said they had a little improvement on medication, but the majority stated that they had no relief from pain whatsoever.

At the end of the trial we found that tablets A were those containing $2 \frac{1}{2}$ gr. aspirin and that tablets $B$ were those containing $7 \frac{1}{2}$ gr. calcium orthoiodoxybenzoate.

We therefore have not found any evidence from this series that the latter drug has any effect in the above types of cases. No toxic manifestations of any description were noted during this trial.

\section{Summary}

Twenty-seven patients were given identical physical treatment except that fourteen received tablets $\mathrm{A}$, containing $2 \frac{1}{2} \mathrm{gr}$. aspirin, and thirteen received tablets B, containing $7 \frac{1}{2}$ gr. calcium ortho-iodoxybenzoate (Arthrytin). No one concerned in the trial was aware which tablets were which. Those receiving tablets A showed subjective improvement in varying degrees, the rest reported little or no relief.

We have to thank Messrs. May and Baker Ltd. for kindly supplying the tablets, and Dr. W. R. Thrower for his advice and help.

\section{REFERENCES}

Cohen, A. (1937). Clin. med. Surg., 44, 341.

Cottrell, J. E. (1927). Amer. J. med. Sci., 174, 623.

Harbinson .J. E. (1929). Calif. West. Med., 31, 24.

Hartmann, C., and Meyer, V. (1893). Ber. dtsch. Chem. Ges., 26, 1727.

Pemberton, R. (1929). "Arthritis and Rheumatoid Conditions",, p. 283. Lea and Febiger, Philadelphia. Baillière, London, 2nd ed. (1935).

Smith, M. (1927). Boston med. surg. J., 196, 305.

(1928). N. Engl. J. Med., 199, 133.

Young, A. G. (1928). Ibid., 199, 1194.

-, and Youmans, J. B. (1926). J. Amer. med. Ass., 87, 746.

\section{Essai Clinique de l'Ortho-iodoxybenzoate de Calcium}

\section{RÉSUMÉ}

On administra un traitement physique identique à vingt-sept malades; toutefois quatorze d'entre eux eurent des comprimés A, contenant env. $0 \cdot 16 \mathrm{~g}$. d'aspirine, tandis qu'on donna aux treize autres des comprimés B, contenant env. $0.5 \mathrm{~g}$. d'ortho-iodoxybenzoate (Arthrytin). Aucun des sujets soumis à l'essai ne savait quels comprimés il avait absorbé. Ceux qui avait pris des comprimés A montrèrent une amélioration subjective d'un dégré variable. Les autres ne manifestèrent aucun ou peu de soulagement.

\section{Ensayo Clinico del Orto-iodoxibenzoato de Calcio RESUMEN}

Un tratamiento físico idéntico fué administrado a veintisiete enfermos; catorce de ellos, sin embargo, tomaron comprimidos A conteniendo $0 \cdot 16 \mathrm{~g}$. de aspirina, mientras que trece otros tomaron comprimidos B conteniendo $0.5 \mathrm{~g}$. de orto-iodoxibenzoato (Arthrytin). Ninguno de los sujetos sometidos al experimento podía distinguir entre los comprimidos. Los que habían tomado los comprimidos A mostraron mejoría subjetiva de grado variable. El alivio de los demás fué poco o ninguno. 